\title{
Does Mixing Tree Species Affect Water Storage Capacity of the Forest Floor? Laboratory Test of Pine-Oak and Fir-Beech Litter Layers
}

\author{
Anna Ilek ${ }^{1,2, * \mathbb{C}}$, Małgorzata Szostek ${ }^{3} \mathbb{D}$, Anna Mikołajczyk ${ }^{2}$ and Marta Rajtar ${ }^{2}$ \\ 1 Department of Botany and Forest Habitats, Faculty of Forestry and Wood Technology, Poznań University of \\ Life Sciences, Wojska Polskiego 71f, 60-625 Poznań, Poland \\ 2 Department of Forest Utilization, Engineering and Forest Technology, Faculty of Forestry, University of \\ Agriculture in Krakow, Al. 29 Listopada 46, 31-425 Krakow, Poland; anna.ka.palasz@gmail.com (A.M.); \\ marta.rajtar1995@gmail.com (M.R.) \\ 3 Department of Soil Science, Environmental Chemistry and Hydrology, College of Natural Sciences, \\ University of Rzeszów, Zelwerowicza 8b, 35-601 Rzeszów, Poland; mszostek@ur.edu.pl \\ * Correspondence: anna.ilek@up.poznan.pl; Tel.: +48-618466031
}

Citation: Ilek, A.; Szostek, M.; Mikołajczyk, A.; Rajtar, M. Does Mixing Tree Species Affect Water Storage Capacity of the Forest Floor? Laboratory Test of Pine-Oak and Fir-Beech Litter Layers. Forests 2021, 12, 1674. https://doi.org/10.3390/ f12121674

Received: 7 November 2021 Accepted: 29 November 2021 Published: 30 November 2021

Publisher's Note: MDPI stays neutral with regard to jurisdictional claims in published maps and institutional affiliations.

Copyright: (c) 2021 by the authors. Licensee MDPI, Basel, Switzerland. This article is an open access article distributed under the terms and conditions of the Creative Commons Attribution (CC BY) license (https:/ / creativecommons.org/licenses/by/ $4.0 /)$.

\begin{abstract}
During the last decade, tree species mixing has been widely supported as a silvicultural approach to reduce drought stress. However, little is known on the influence of tree species mixing on physical properties and the water storage capacity of forest soils (including the forest floor). Thus, the study aimed to analyze the effect of mixing pine needles and oak leaves and mixing fir needles and beech leaves on hydro-physical properties of the litter layer during laboratory tests. We used fir-beech and pine-oak litter containing various shares of conifer needles (i.e., 0, 5, 10, 20, 30, 40, 50, $60,70,80,90$ and $100 \%$ ) to determine the influence of the needle admixture on bulk density, total porosity, macroporosity, water storage capacity, the amount of water stored in pores between organic debris and the degree of saturation of mixed litter compared to broadleaf litter (oak or beech). We found that the admixture of fir needles increased the bulk density of litter from $7.9 \%$ with a $5 \%$ share of needles to $55.5 \%$ with a $50 \%$ share (compared to pure beech litter), while the share of pine needles $<40 \%$ caused a decrease in bulk density by an average of 3.0-11.0\% (compared to pure oak litter). Pine needles decreased the water storage capacity of litter by about $13-14 \%$ with the share of needles up to $10 \%$ and on average by $28 \%$ with the 40 and $50 \%$ shares of pine needles in the litter layer. Both conifer admixtures reduced the amount of water stored in the pores between organic debris (pine needles more than fir needles).
\end{abstract}

Keywords: forest hydrology; hydro-physical properties of litter layer; fir-beech litter; pine-oak litter; mixed stands

\section{Introduction}

Recent research examining global climate changes indicates that drought conditions have increased globally in the last 40-50 years [1]. Across much of the temperate zone, further increase in drought frequency is predicted [2-5], which is likely to be particularly consequential for forests. According to [6], drought occurs under low levels of available water, caused by reduced precipitation and increased atmospheric evaporative demand combined with low available soil water. Drought may lead to reduced photosynthesis, increased defoliation, as well as decreased tree and stand growth [7]. Unlike gradual climate change, the direct and indirect effects of drought will contribute to significant ecological and financial losses, in view of which investigating the response of trees to extreme drought is of great interest [8].

During the last decade, tree species mixing has been widely supported as a silvicultural approach to reduce drought stress, because mixing tree species with various ecological and resistance traits may mitigate adverse growth effects [7]. Many studies concerned the 
sensitivity of different tree species inside mixed stands to water stress during drought. Many of these investigations focused on the hydraulic properties of leaves and stems as a reaction to drought episodes [9-12]. However, in order to deal with drought effects, trees adopt numerous belowground strategies (e.g., root architecture and depth, root access to deep water) that likely interact with soil properties and soil biota [13-15]. For this reason, taking into account only the aboveground traits of trees without consideration for belowground traits and site conditions may lead to erroneous projections of drought consequences. Any generalization or theory needs to be based on a broad overview of the mixing reactions of functionally different tree species investigated in different mixing proportions, patterns and under different site conditions [16].

Little is known on the influence of tree species mixing on physical properties and soil water storage capacity, and consequently the indirect impact of mixed stands on drought prevention. The species composition may affect soil properties through litterfall, composing the forest floor on the soil surface. Although vegetation response to the changing climate has been effectively measured and modeled, less is known about how these changes will be reflected in changes in soil C, which in part is because soil C stocks cannot be measured as easily as vegetation biomass over broad geographic scales [17]. Soil organic matter (SOM) consists of fresh or undecomposed, partially decomposed, and fully decomposed organic matter [18]. The soil surface layer of organic dead debris in various stages of decomposition constitutes a forest floor, of which size and structure are a natural function of vegetation type, climate and time [19]. The thickness of the forest floor varies both within and between ecosystems and is increased with decreasing soil fertility [20]. The forest floor is an active component of the forest ecosystems and plays different functions in them. It is a significant reservoir of organic matter and nutrients, while it is also a protective layer against microclimate fluctuations, soil compaction and erosion [21,22]. Moreover, the forest floor plays a vital role in the forest water balance by controlling water fluxes and reducing water and soil losses as a result of decreasing the kinetic energy of raindrops and the amount of rainfall reaching the soil [20,23,24]. Helvey [25] stated that annual forest floor interception losses of conifers range from 2 to $17 \%$ of gross rainfall, whereas Sun et al. [26] reported that forest floor interception might amount to $10-19 \%$ of gross rainfall. In an evergreen forest litter interception may consist of $8.9 \%$ of annual rainfall [27].

A clear arrangement of horizons is visible in a well-developed forest floor, from freshly fallen leaves and twigs in the highest layers to the lowest layer of humus, with an advanced degree of decomposition [18]. These horizons are usually identified as the $\mathrm{L}$ (litter), F (fermented) and H (humus) layers, with each being characterized by various physical and chemical properties that affect their water holding capacity [28]. Forest litter is the primary source of soil organic matter in a forest ecosystem and acts as an insulating layer that protects the soil from extreme fluctuations in moisture content and temperature [22]. Litter layer properties are determined by vegetation type, species composition, season and forest management practices [28,29]. Tree species have consistent effects on forest floor $\mathrm{pH}$ and nutrient concentrations [30]. According to Zagyvai-Kiss [31], the water holding capacity of the litter layer is an essential parameter for hydrological modeling due to the ability of litter to change the quantities of water available for soil infiltration and runoff.

For the development and implementation of appropriate forest management practices, it is essential to understand the spatial and temporal distribution of droughts and their relationship with tree species growing in these areas and take into account the vulnerability of individual species to drought stress [32]. Insight into forest litter hydrologic dynamics is necessary to provide land managers with practical information facilitating the rational management of forest resources [33], especially in the context of mitigating adverse effects of drought and broadening knowledge on the impact of individual tree species (and their mixing) on water retention in forest soils, including the forest floor. Thus, the study aimed to analyze the effect of mixing pine needles and oak leaves and mixing fir needles and beech leaves on hydro-physical properties of the litter layer during laboratory tests. The null hypotheses tested in this study are as follows: (1) hydro-physical properties of the 
litter layer are relatively constant, regardless of the stand species composition, and thus (2) the mixing of tree species does not have a significant effect on hydro-physical properties of the litter layer.

The rejection of the null hypotheses may indicate that the morphological traits of the litterfall resulting from their botanical origin affect hydro-physical properties of the litter layer, and by mixing tree species it may be possible to improve the retention capacity of forest soils, which merits further research.

\section{Materials and Methods}

\subsection{Study Site}

We collected oak leaves, pine needles, beech leaves and fir needles from litter layers of four one-species forest stands in southern Poland promptly after the fresh litter fall (late November). Oak leaves were collected in a broadleaved lowland forest $\left(50.0902^{\circ} \mathrm{N}\right.$, $20.3641^{\circ} \mathrm{E}$ ) with the predominance of pedunculate oak (Quercus robur L.), while pine needles were collected in a coniferous lowland forest $\left(50.0752^{\circ} \mathrm{N}, 20.4093^{\circ} \mathrm{E}\right)$ with Scots pine (Pinus sylvestris L.) as the dominant species. In contrast, beech leaves and fir needles were collected in mountain broadleaved $\left(49.3300^{\circ} \mathrm{N}, 20.9434^{\circ} \mathrm{E}\right)$ and coniferous forests $\left(49.3236^{\circ} \mathrm{N}, 20.9347^{\circ} \mathrm{E}\right)$, in which European beech (Fagus sylvatica L.), and silver fir (Abies alba Mill.), respectively, were dominant species (Figure 1). All the stands are situated in a temperate climate zone. The above species are among the main forest-forming tree species in Poland. Scots pine is a dominant species in $58.2 \%$ of Polish forests, while pedunculate oak, European beech and silver fir dominate in 7.7, 6.0 and $3.2 \%$ of forest area in Poland, respectively [34].

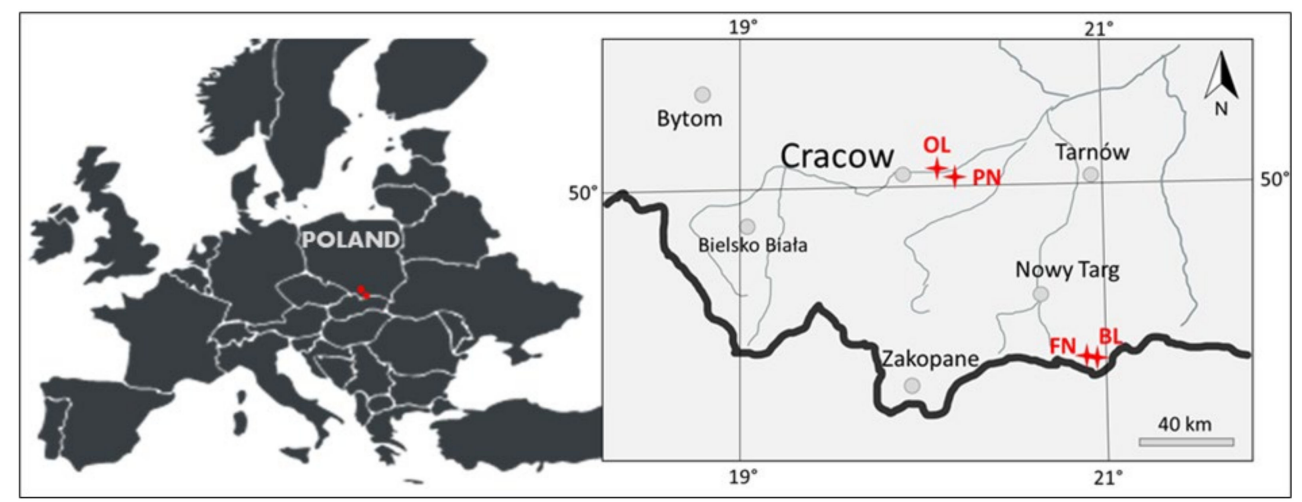

Figure 1. Location of litter sample collection sites in southern Poland, where OL, PN, BL, and FN are forest areas where oak leaves, pine needles, beech leaves and fir needles were collected, respectively.

\subsection{Laboratory Tests}

All leaves and needles collected from the litter layers of particular stands were first airdried under laboratory conditions. Experiments were started by determining the moisture content of air-dried leaves or needles, the maximum moisture content of leaves or needles of particular tree species and their bulk density. To measure these properties, we prepared 130 air-dry leaf and needle samples, including 35 pine samples, 35 fir samples, 30 oak samples and 30 beech samples. Each pine and fir sample contained 40 needles, whereas each oak and beech sample was composed of five leaves. Particular samples were first weighed (air-dried mass) and then were soaked in water to fill the internal capillarity of organic debris, i.e., until the water-soaked leaves and needles reached the density of more than $1.0 \mathrm{~g} \mathrm{~cm}^{-3}$ and fell to the bottom of the beaker [35,36]. After a given sample was extracted from the water, we removed the excess water from the surface of the leaves using damp paper and measured the mass of wet leaves or needles. Next, we determined their volume in a graduated cylinder using the water displacement method and afterward each sample was dried at $105^{\circ} \mathrm{C}$ for $24 \mathrm{~h}$ and weighed again. The moisture content $M C_{N L}(\%)$ 
of air-dried leaves and needles and their maximum moisture content were calculated according to the formula:

$$
M C_{N L}=\frac{m_{x}-m_{s}}{v} \cdot 100
$$

where $m_{x}$ is the mass of air-dried or wet leaves or needles $(\mathrm{g}), m_{s}$ is the dry mass of leaves or needles $(\mathrm{g}), v$ is the volume of leaves or needles $\left(\mathrm{cm}^{3}\right)$.

The bulk density of leaves or needles $\mathrm{BD}_{\mathrm{NL}}\left(\mathrm{g} \mathrm{cm}^{-3}\right)$ was calculated as a ratio of $m_{s}$ to $v$.

To determine the effect of mixing tree species on hydro-physical properties of the litter layer, we used two types of mixed litter: fir-beech and pine-oak. For a given type of litter, artificial samples were prepared with various shares of conifer needles, i.e., 0, 5, 10, 20, $30,40,50,60,70,80,90$ and 100\% (Figure 2A). We prepared each sample according to the method shown in Figure 2B. First, we weighed the previously calculated masses of air-dried leaves and needles, which after mixing had the appropriate proportions (listed above). The shares of leaves and needles refer to their dry mass; therefore, during weighing the moisture content of air-dried leaves and needles was considered, as calculated following Equation (1) ( 15\%). Next, the leaves and needles were soaked in water until they fell onto the bottom of the beaker. After the leaves were drained and excess water was removed from their surface using damp paper, the wet mass of leaves and needles was determined and then they were placed in a $0.25 \mathrm{~mm}$ sieve inside a bowl with water. Submerged needles and leaves were mixed thoroughly and afterwards with one quick movement the sieve was pulled out of the water. The mixing of submerged leaves and needles ensured their random distribution on the sieve surface and the same conditions of preparing all artificial samples. The litter deposited on the sieve surface was drained, weighed and then the distance between the top edge of the sieve and the litter surface was measured in twenty-five points (Figure 2B). Litter thickness and volume were calculated based on the sieve volume and the average distance from the top edge of the sieve to the litter surface. Then each litter sample was dried at $105^{\circ} \mathrm{C}$ to a constant mass. We prepared 60 artificial litter samples for each type of mixed litter (five samples per given proportion needles to leaves, i.e., 120 samples).

We calculated bulk density $B D$, total porosity $T P$, water storage capacity $P_{K}$, macroporosity $M P$, the amount of water stored in pores between organic debris $P W$ and the degree of saturation $S W$ for each artificial litter sample. $\mathrm{V}\left(\mathrm{cm}^{3}\right)$.

$B D\left[\mathrm{~g} \mathrm{~cm}^{-3}\right]$ was calculated as a ratio of dry mass $M_{S}[\mathrm{~g}]$ to the volume of litter sample

$T P\left[\mathrm{~cm}^{3} \mathrm{~cm}^{-3}\right]$ was calculated according to the following formula:

$$
T P=\frac{S D-B D}{S D}
$$

where $S D$ is specific density of $1.375 \mathrm{~g} \mathrm{~cm}^{-3}$, calculated as the average of specific density measurements of 20 samples containing fir needles, beech leaves, pine needles, oak leaves and their mixes. Specific density was measured using the pycnometer method in $99.8 \%$ ethyl alcohol [37].

$P_{K}[\mathrm{~mm}]$ was calculated according to the following formula:

$$
P_{K}=\left(\frac{V_{\mathrm{H}_{2} \mathrm{O}}}{V}\right) \cdot 10
$$

where $V_{\mathrm{H} 2 \mathrm{O}}$ is the volume of water stored in the litter calculated from the difference between the wet and dry mass of litter (assuming a water density of $1 \mathrm{~g} \mathrm{~cm}^{-3}$ ), $V$ is the volume of litter $\left(\mathrm{cm}^{3}\right), 10$ is a conversion factor to result in $\mathrm{mm}$ of water in the litter with a thickness of $1 \mathrm{~cm}$. 


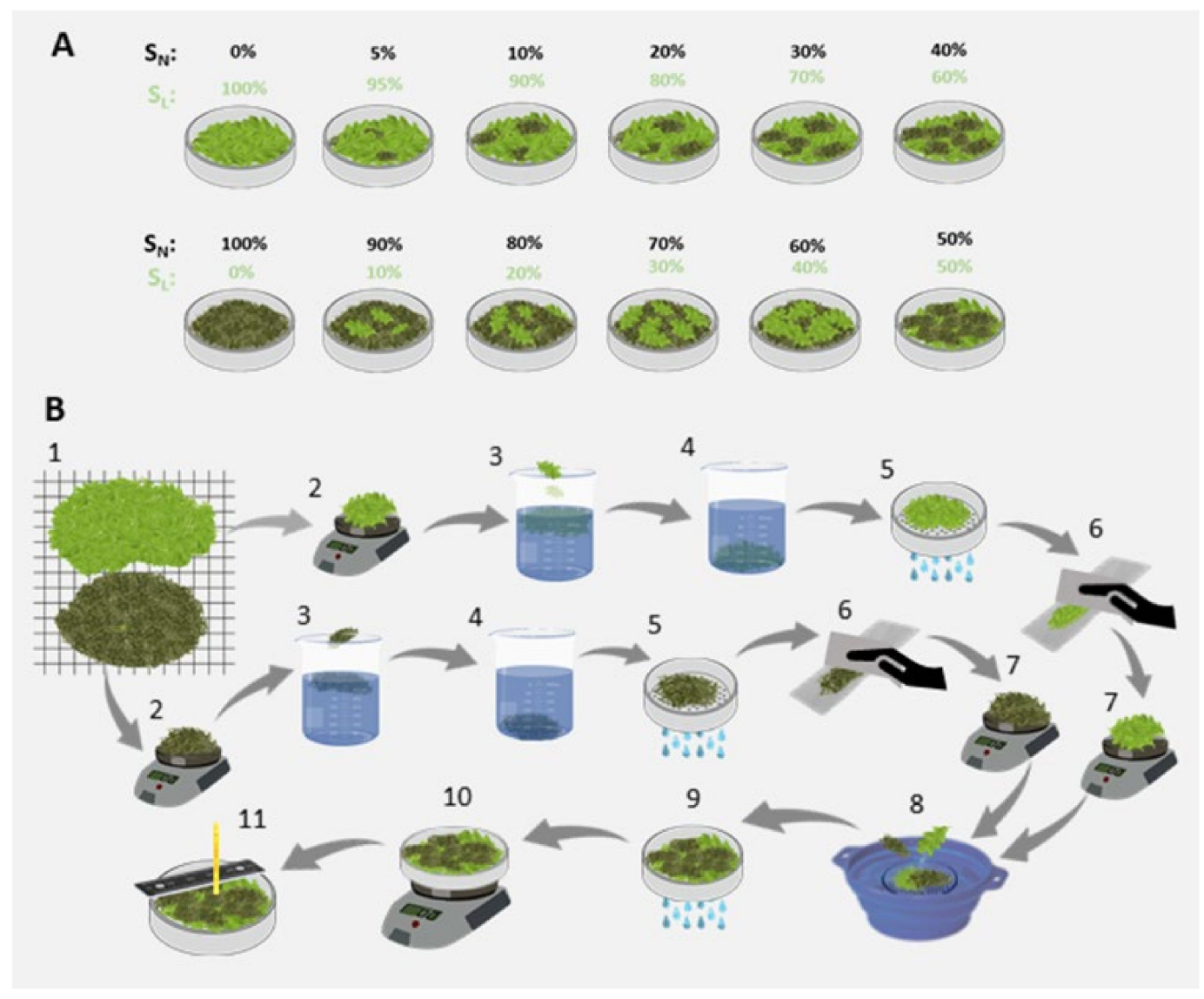

Figure 2. (A) Variants of artificial pine-oak or fir-beech litter samples with different shares of needles $\left(\mathrm{S}_{\mathrm{N}}\right)$ and leaves $\left(\mathrm{S}_{\mathrm{L}}\right)$ used in laboratory tests. (B) The scheme of artificial litter sample preparation during laboratory tests, where $1-$ drying of collected needles and leaves under laboratory conditions, 2-weighing of air-dried needles and leaves in appropriate proportions, 3-immersion of needles and leaves in water, and 4-soaking them until water-soaked leaves and needles fell to the beaker bottom, i.e., when they reached the density of more than $1.0 \mathrm{~g} \mathrm{~cm}-3,5$ - draining of wet leaves and needles, 6 -removing excess water from the surface of leaves and needles using damp paper, 7-measuring the wet mass of leaves and needles, 8-mixing submerged leaves and needles on the sieve, 9-draining of mixed litter sample deposited on the sieve, 10-measuring the wet mass of litter, and 11-measuring the litter thickness and volume.

$M P\left[\mathrm{~cm}^{3} \mathrm{~cm}^{-3}\right]$ was calculated according to the equation:

$$
M P=T P-\left(\frac{V_{\mathrm{H}_{2} \mathrm{O}}}{V}\right)
$$

$P W$ is a part of the water storage capacity of the litter, corresponding to the amount of water stored between the organic debris (also on its surface), disregarding the internal capillarity of needles and leaves. $P W[\mathrm{~mm}]$ was calculated according to the equation:

$$
P W=\left(\frac{M_{w}-M_{L}-M_{N}}{V}\right) \cdot 10
$$

where $M_{w}$ is the wet mass of litter, $M_{L}$ and $M_{N}$ is the wet mass of leaves and needles, respectively, determined after draining of leaves and needles and removing excess water from their surface (Figure $2 b$ ).

$S W$ is the degree of filling all litter pores with water. SW (\%) was calculated according to the formula:

$$
S W=\left(\frac{V_{\mathrm{H}_{2} \mathrm{O}}}{V} \cdot T P^{-1}\right) \cdot 100
$$




\subsection{Statistical Analysis}

The statistical analysis and associated graphics were performed in Statistica 13.3 PL (StatSoft Inc., Tulsa, OK, USA). Significant differences in hydro-physical properties of leaves/needles and litter between particular tree species were tested by one-way ANOVA and post-hoc Tukey's test after checking normality by the Shapiro-Wilk test and the equality of variance by Levene's test. In the case of the non-parametric data, the Kruskal-Wallis test was applied. To compare the hydro-physical properties of litter between two species (e.g., oak vs. beech) or between coniferous (pine and fir) and broadleaved tree species (beech and oak) the $t$-test was used, whereas in the case of the non-parametric nature of data the Mann-Whitney U test was applied. All the tests were performed at a significance level of 0.05 .

\section{Results}

\subsection{Bulk Density and Moisture Content of Leaves and Needles}

The bulk density of the needles ranged from 0.308 to $0.404 \mathrm{~g}$, while the bulk density of the leaves ranged from 0.265 to $0.373 \mathrm{~g} \cdot \mathrm{cm}^{-3}$ (Figure 3A). The bulk density of the leaves was on average $13.9 \%$ lower than that of the needles, with significant differences between the coniferous species $(p<0.001)$ and no differences between the broadleaved species $(p=0.285)$. The bulk density of pine needles was on average $14.0 \%$ greater than that of the other species, with the largest difference observed between pine and oak $(p<0.001)$ (Figure 3A).
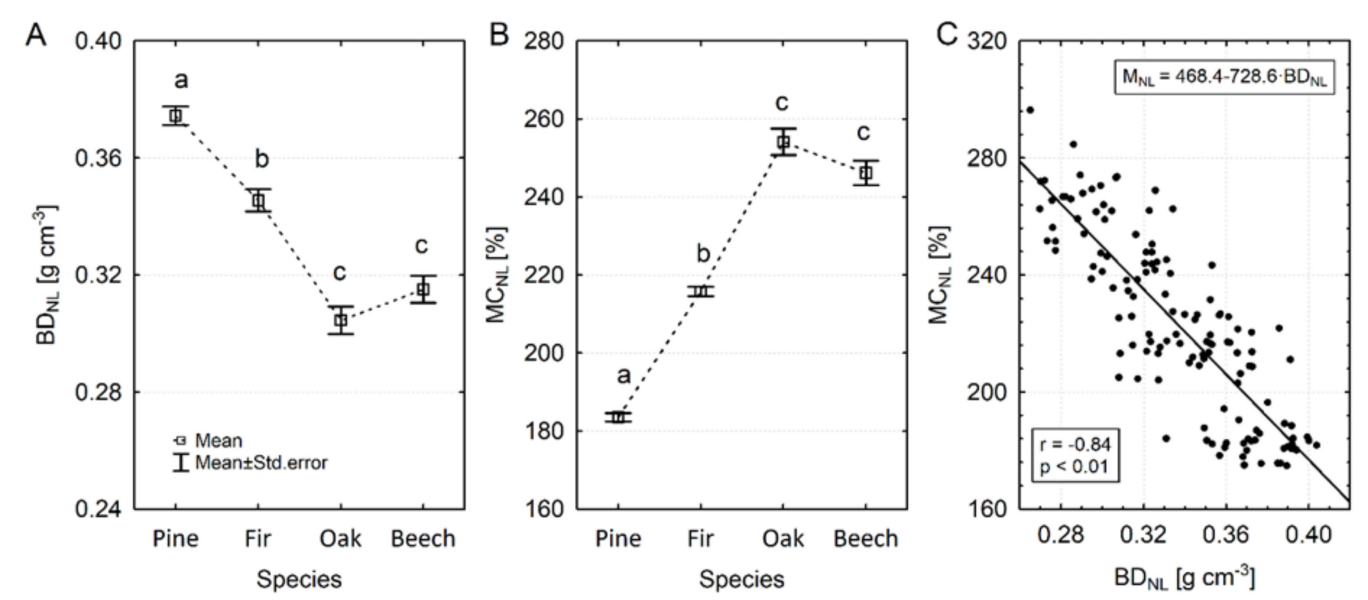

Figure 3. (A) Variability of bulk density and (B) maximum moisture content of needles and leaves of a particular tree species, and (C) correlation between the maximum moisture content of needles and leaves and their bulk density. Different letters indicate significant differences between tree species determined using Tukey's (A) and the Kruskal-Wallis (B) tests $(p<0.05)$.

The maximum moisture content of the needles and leaves ranged from $175 \%$ to $233 \%$ and $214 \%$ to $296 \%$, respectively (Figure 3B). Overall, the moisture content of the leaves was $20.2 \%$ greater than that of the needles, with significant differences between the coniferous species $(p<0.001)$ and no differences between the broadleaved species $(p=0.870)$. Oak leaves reached the highest moisture content $(254.1 \pm 3.4 \%)$, which was 15.1 and $27.8 \%$ higher than the moisture content of fir and pine needles, respectively (Figure 3B). Similarly, the moisture content of beech leaves was 12.3 and $25.4 \%$ higher than that of fir and pine needles, respectively. We observed a clear relationship between the maximum moisture content and the bulk density of the leaves and needles (Figure 3C).

\subsection{Hydro-Physical Properties of Pure Litter Layers}

The oak and beech litters had similar hydro-physical properties, with no significant differences observed between these species in terms of bulk density $(p=0.506)$, total 
porosity ( $p=0.506)$, macroporosity $(p=0.685)$, water storage capacity $(p=0.707)$, amount of water stored in pores between organic debris $(p=0.957)$ and the degree of saturation $(p=0.706)$ (Figure 4). Among all the species, fir litter had the highest bulk density, water storage capacity, degree of saturation and the lowest total porosity, macroporosity and amount of water stored in pores. Macroporosity, water storage capacity and the degree of saturation in pine litter were similar to those of broadleaved species. The bulk density of pine litter was on average $47.8 \%$ higher than the bulk density of broadleaved litter and $56.7 \%$ lower than that of fir litter. The total porosity of pine litter and the amount of water stored in pores were 1.5 and $64.3 \%$ lower than those in broadleaved litter and 4.6 and $31.0 \%$ higher than in fir litter (Figure 4).

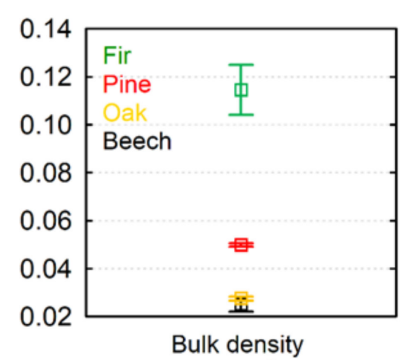

$\left[\mathrm{g} \mathrm{cm}^{-3}\right.$ ]

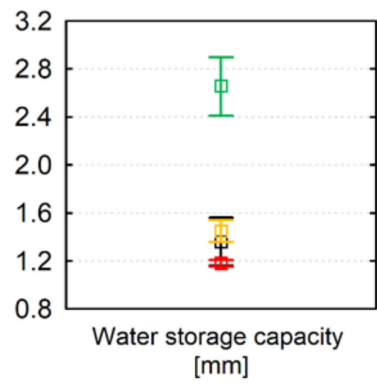

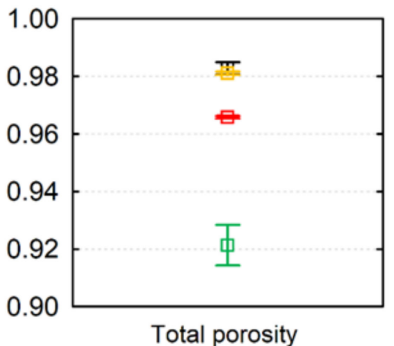

$\left[\mathrm{cm}^{3} \mathrm{~cm}^{-3}\right.$ ]

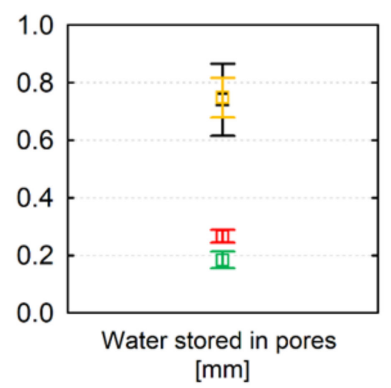

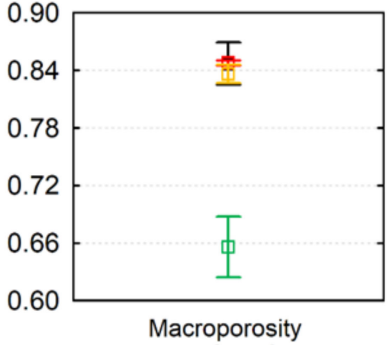

$\left[\mathrm{cm}^{3} \mathrm{~cm}^{-3}\right]$

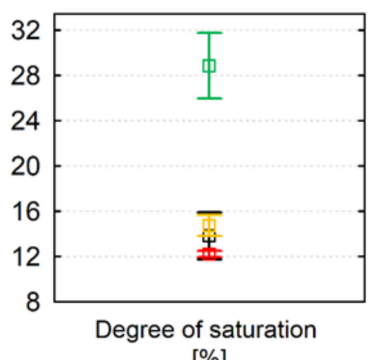

[\%]

Figure 4. Hydro-physical properties of pure fir, pine, beech and oak litter layers (mean $\pm \mathrm{SE}$ ).

\subsection{The Impact of Mixing Tree Species on Hydro-Physical Properties of the Litter Layer}

The percentage changes in the hydro-physical properties of the litter layer (relative to pure beech or oak litter) resulting from the share of the coniferous admixture in the litter (fir or pine needles) are shown in Figure 5.

The admixture of fir needles increased the bulk density of litter from $7.9 \%$ with a $5 \%$ share of needles to $55.5 \%$ with a $50 \%$ share, while the share of pine needles $<40 \%$ caused a decrease in bulk density by an average of 3.0-11.0\%. Both fir and pine needles had a slight effect on the total porosity of litter, while at a $50 \%$ share of needles they reduced porosity by less than $1 \%$ relative to broadleaved litter. The admixture of fir needles did not exert much influence on litter macroporosity, whereas with their 50\% share macroporosity decreased by less than 1\% compared to pure beech litter. In turn, pine needles increased litter macroporosity (compared to pure oak litter) by $2.3 \%$ with a $10 \%$ share of needles and by $5.1 \%$ in the case of the $30 \%$ share (Figure 5). The admixture of fir needles had no significant effect on the water storage capacity of the litter or its degree of saturation (Figure 5). Pine needles decreased the water storage capacity of litter by about $13-14 \%$ with the share of needles up to $10 \%$ and on average by $28 \%$ with the 40 and $50 \%$ shares of pine needles in the litter layer. A similar effect of pine needles was observed for the degree of saturation. Both conifer admixtures reduced the amount of water stored in the pores between organic debris (pine needles more than fir needles). With a $5 \%$ share of pine needles the amount of water stored in pores decreased on average by $16 \%$ (in the case of fir by $2.5 \%$ ), while with a $50 \%$ share it decreased by $46 \%$ (in the case of fir by 36\%) (Figure 5). 

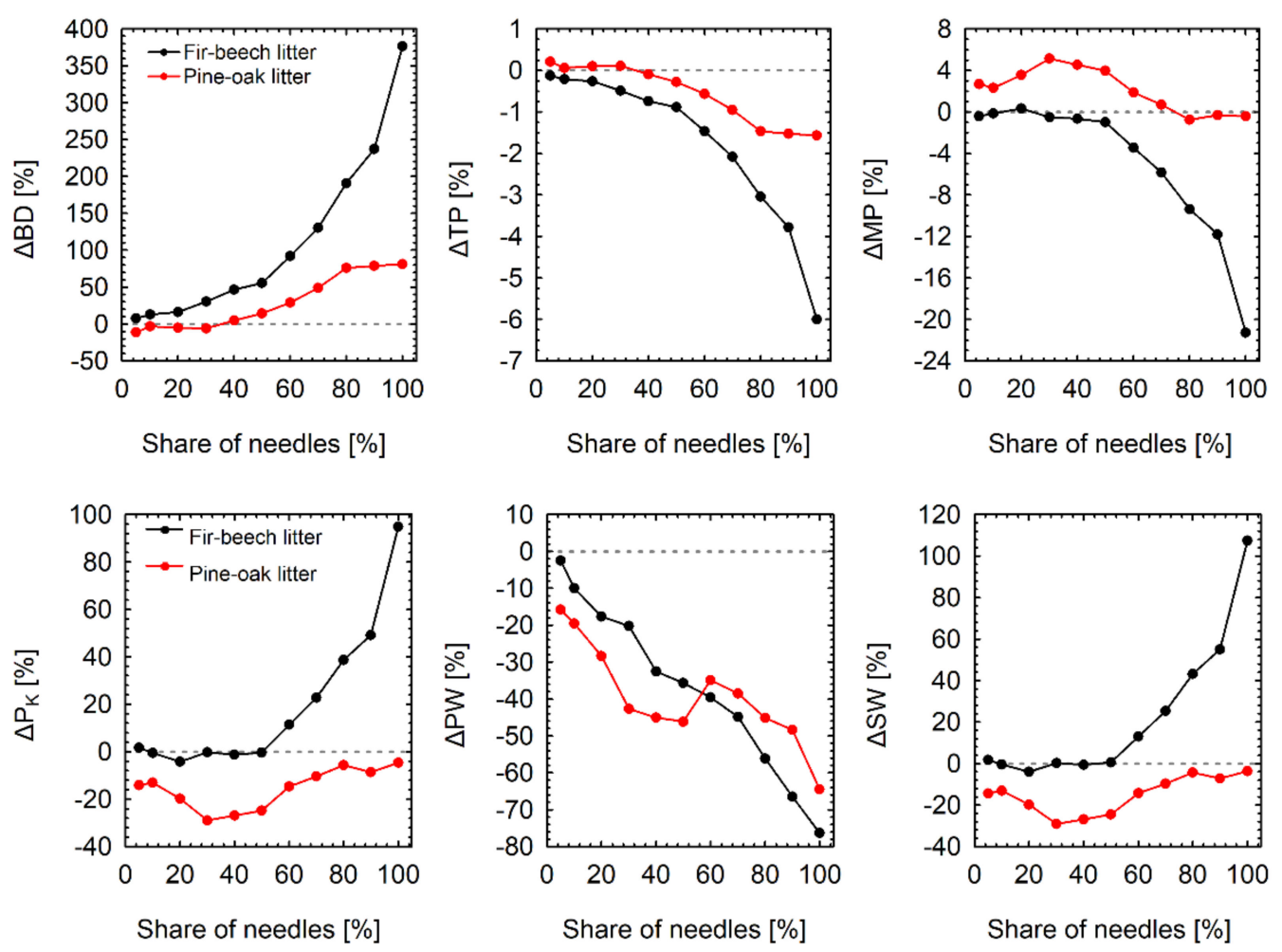

Figure 5. Percentage changes in bulk density $(\Delta \mathrm{BD})$, total porosity $(\Delta \mathrm{TP})$, macroporosity $(\Delta \mathrm{MP})$, water storage capacity $\left(\Delta \mathrm{P}_{\mathrm{K}}\right)$, amount of water stored in pores $(\Delta \mathrm{PW})$, and degree of saturation $(\Delta \mathrm{SW})$ of the litter layer (relative to pure beech or oak litter) resulting from the share of coniferous admixture in the litter (fir or pine needles).

\section{Discussion}

We chose pine-oak and fir-beech litters for our study for several reasons. Scots pine and oak are economically very important tree species in Europe. Scots pine is the most widespread species of the Pinus genus globally and the second most widespread conifer after common juniper (Juniperus communis) [38,39]. In Europe, the area of Scots pine forests exceeds 28 million hectares, comprising over $20 \%$ of the productive forest area [40], while in Poland they cover the majority of the country's forest area (58.2\%), constitute the largest share in forests managed by the State Forests $(60.3 \%)$, and slightly smaller in private forests (55.0\%) [34]. Scots pine and oak are widely considered to be promising tree species that allow forest managers to reduce risks associated with climate change (e.g., droughts, wildfires) [16] and this mixture has been quite natural and common in the past [41]. In the mixture, both species currently cover approximately $1.3 \times 10^{6}$ ha in Europe, with a potential distribution area of $35 \times 10^{6}$ ha [16]. Beech and fir-beech forests represent the dominant community of potential natural vegetation from the planar to montane zones of Central European temperate forests. They are the dominant forest communities in the Carpathians that form a part of the Central- and East-European region of mixed broadleaved-coniferous forests. Currently, the development of beech is the opposite of that of fir, and beech becomes definitely dominant in the Carpathian natural fir-beech forests and governs their current developmental dynamics [42,43].

The different bulk densities and maximum moisture contents recorded for the leaves and needles of individual tree species indicate that the botanical origin of dead organic debris determines their initial physical properties, affecting the litter layer's water storage capacity (Figure 3). The maximum moisture content of pine needles was on average $\sim 28 \%$ and $\sim 25 \%$ less than the moisture content of oak and beech leaves, respectively (Figure $3 \mathrm{~B}$ ). Similarly, Walsh and Voigt [44] stated that individual beech leaves retain one and a half times the amount of water that pine needles do. This is related to the contrasting physical 
characteristics of dead leaves and needles, notably the much greater surface area/weight ratio of beech leaves. The low moisture content of pine needles may be caused by the fact that they are well adapted to cold and drought, i.e., pine needles have embedded stomata and a thick-walled epidermis with a wax layer protecting the needle from water loss [39].

Variation in the hydro-physical properties of pure litter layers indicates that they are probably dependent on the structure and size of the pore spaces, determined by the size of organic debris [45] (thus Hypothesis 1 was rejected). Silver fir has flattened needles, $1.5-3.0 \mathrm{~cm}$ long and $\sim 2 \mathrm{~mm}$ wide, while Scots pine needles are $2.5-9.0 \mathrm{~cm}$ long and 1.5-2.0 mm wide [46], whereas leaves of European beech are 5-6 cm long and 3.2-3.8 cm wide [47]. The length and width of English oak leaves amount to $7.3-15.2 \mathrm{~cm}$ and $2.5-7.3 \mathrm{~cm}$, respectively, with the broadest portion toward the outer end of the leaf [48]. The large size of beech and oak leaves results in a low bulk density, high porosity and macroporosity, low water storage capacity and degree of saturation. The small size of fir needles affected the high litter density, low total porosity, and macroporosity, which increased water storage capacity and degree of saturation of this litter compared to the other species (Figure 4). Some studies also report that stand species composition affects the water storage capacity of the litter layer. For example, Ilek et al. [28] found that the water storage capacity of beech (F. sylvatica), fir (A. alba) and spruce (P. abies) litter was 1.6, 2.8, and $4.44 \mathrm{~mm}$, respectively, which well corresponds with our results (Figure 4). Spruce needles are 1-2.5 cm long and 4-angled in cross-section [49], so they were the tiniest among all the examined species, which is probably why the water storage capacity of the spruce litter layer was high. According to Putuhena and Cordery [50], the water storage capacity of pine and eucalyptus litter amounts to 2.3 and $1.4 \mathrm{~mm}$, respectively. Gerrits [51] found that the water storage capacity of beech litter is about $44 \%$ greater than that of cedar litter.

Interestingly, conifer litter stored significantly less water in pores between organic debris than broadleaved litter $(p<0.001)$. In the fir litter, water stored in the pores constituted on average $6.9 \pm 0.8 \%$ of the water storage capacity, while in the pine, oak and beech litters it was $22.5 \pm 1.5 \%, 51.5 \pm 1.6 \%$, and $54.1 \pm 2.0 \%$, respectively (Figure 4 ). It indicates that water in the fir litter is stored mainly inside organic debris, while broadleaved litter (despite high macroporosity) stores above $50 \%$ water outside of organic debris, probably mainly on the surface of leaves. It corresponds with the findings of Sato et al. [52], who argued that water storage capacity of litter layers was proportional to the litter mass regardless of layer thickness; this signified that the storage of the litter layer may not be determined by the "capillary water" held in the gaps created between litters, but by the "adhesion water" held by each litter surface [53]. Taking into account the relatively fast water absorption time of beech leaves amounting to about one day [36], it can be assumed that wet, heavy and large leaves flatten and adhere to each other, which may also increase the amount of water stored between organic debris in the broadleaved litter.

The effect of mixing tree species on hydro-physical properties of litter can be considered in two ways: 1) for the admixture of coniferous organic matter in a broadleaved stand, and 2) for the admixture of broadleaved organic matter in a coniferous stand. In general, needles as an admixture in broadleaved litter decreased the amount of water stored in pores between organic debris, while leaves as an admixture in the coniferous litter increased the amount of water stored outside the organic debris and decreased the water storage capacity and degree of saturation (Figure 5) (thus Hypothesis 2 was rejected). Needles between leaves in the litter prevent wet leaves from sticking to one another and increase water infiltration through the litter, reducing the amount of water stored in pores between organic debris in the mixed litter. Zema et al. [54] found that soil water infiltration was greater in the Pinus + Juniper mixed forest and the Pinus + Quercus + Juniper mixed forests compared to the monospecies forest. Fernald et al. [33] observed that mixed coniferous stands produced a higher runoff rate $\left(5.18 \pm 1.11 \mathrm{~cm} \mathrm{hr}^{-1}\right)$ than ponderosa pine $\left(3.6 \pm 0.64 \mathrm{~cm} \mathrm{hr}^{-1}\right)$. Needle litter allowed the moisture to drain in a more vertical pattern, resulting in lesser potential for interception [50]. The low impact of the fir needle admixture on the water storage capacity of the litter (compared to pure beech litter) and 
the degree of saturation (despite the increase in its bulk density) may be related to the fact that the losses related to the reduced water volume in the pores were compensated for by the relatively high moisture content of the fir needles themselves (Figure 3). The low moisture content of pine needles probably did not compensate for losses in the amount of water stored in pores between organic debris (the more so as pine needles caused an increase in litter macroporosity). In turn, this probably resulted in a reduction of the litter water storage capacity and degree of saturation, despite the slight impact of pine needle admixture on changes in bulk density of the litter and its porosity (compared to pure oak litter). Some studies indicated that mixed litter had a higher water storage capacity than pure coniferous litter [33], but mixed coniferous-broadleaved litter usually showed a lower water storage capacity than mixed coniferous litter $[55,56]$. Mixed stands also influence other properties of the litter. Kara et al. [57] indicated that beech forest has a higher average total litterfall than fir-beech and fir forests in temperate forests in northwestern Turkey $\left(4.2,3.5\right.$, and $2.9 \mathrm{tha}^{-1}$ year $^{-1}$, respectively), and the $\mathrm{C} / \mathrm{N}$ and lignin/ $\mathrm{N}$ ratios were much higher for beech leaves than for fir and fir-beech litters. Błońska et al. [58] found that the admixture of oak in pine stands increases soil microbial activity.

Our results indicate that variation in hydro-physical properties of mixed litter may considerably contribute to small-scale variation in forest floor properties in a mixed stand. The differences in bulk density, total porosity and the macroporosity of pure and mixed litter layers show the initial material's diversity before the beginning of the decomposition process. Hart et al. [59] found that decomposition rates in a mixed conifer forest were found to be significantly higher than that of drier ponderosa pine, with a loss of half the total mass of forest floor litter within the first three months of decomposition. Therefore, in order to better understand the influence of mixed stands on hydrological properties of the forest floor, further research is needed considering the decomposition rate and quality of organic matter in this layer, especially that the $\mathrm{F}$ and $\mathrm{H}$ horizons containing semi-decomposed organic matter usually have a higher water storage capacity than the litter layer $[28,60]$. The limitation of our study is that we conducted experiments only in laboratory conditions. We did not consider the climate and environmental factors that could affect the hydro-physical properties of the litter layer. Future research should consider these factors and the variation of litter properties formed in natural mixed stands. Moreover, to better understand the effect of mixing tree species on soil hydrology under global climate change, further research should consider the impact of drought on the forest floor, i.e., how long-term water deficit periods impact the water repellency of forest floor in mixed and pure stands.

\section{Conclusions}

This study evaluated the effect of mixing pine needles (P. sylvestris) and oak leaves (Q. robur) and mixing fir needles (A. alba) and beech leaves (F. sylvatica) on the hydrophysical properties of the litter layer relative to pure beech and oak litters during laboratory tests. Results revealed the following:

(1) Due to the relatively small size of fir needles, fir litter had the highest bulk density, water storage capacity, degree of saturation, and the lowest total porosity, macroporosity and amount of water stored in pores between organic debris among all the species. The hydro-physical properties of the pine litter layer were closer to the hydro-physical properties of oak and beech litters except for the amount of water stored in pores between organic debris (or on their surface), which was similar to fir litter;

(2) Although the admixture of fir needles increased the bulk density of litter compared to pure beech litter, their influence on total porosity, macroporosity, water storage capacity and the degree of litter saturation was relatively low;

(3) The admixture of pine needles had a slight effect on bulk density and total porosity of litter (compared to pure oak litter), but they increased macroporosity and decreased the water storage capacity and the degree of litter saturation;

(4) Both fir and pine needles decreased the amount of water stored in pores between organic debris (or on its surface), which was probably related to the fact that needles 
between the leaves in the litter prevent wet leaves from sticking to one another and increase water infiltration through the litter.

Author Contributions: Conceptualization, A.I.; methodology, A.I.; software, M.S.; validation, A.I., M.S.; formal analysis, A.I., M.S., A.M. and M.R.; investigation, A.I., A.M., M.R.; resources, A.I., M.S.; data curation, A.I.; writing—original draft preparation, A.I.; writing—review and editing, A.I., M.S.; visualization, A.I. All authors have read and agreed to the published version of the manuscript.

Funding: The present research was partially conducted under a grant for young scientists, founded by the Polish Ministry of Science and Higher Education (No. BM-4448/ZIL/2016). Open Access fees were funded within a subsidy to maintain the Department of Soil Science, Environmental Chemistry and Hydrology research potential of the University of Rzeszów for 2021.

Data Availability Statement: The entire set of raw data presented in this study is available on request from the corresponding author.

Acknowledgments: The authors would like to thank two anonymous reviewers for the thorough assessment of the present paper and for their many valuable and helpful suggestions.

Conflicts of Interest: The authors declare no conflict of interest.

\section{References}

1. Wilhite, D.A. Introduction: Managing drought risk in a changing climate. Clim. Res. 2016, 70, 99-102. [CrossRef]

2. O'Gorman, P.A.; Schneider, T. The physical basis for increases in precipitation extremes in simulations of 21st-century climate change. Proc. Natl. Acad. Sci. USA 2009, 106, 14773-14777. [CrossRef] [PubMed]

3. Dai, A. Drought under global warming: A review. Wiley Interdiscip. Rev. Clim. Chang. 2010, 2, 45-65. [CrossRef]

4. Hoegh-Guldberg, O.; Jacob, D.; Bindi, M.; Brown, S.; Camilloni, I.; Diedhiou, A.; Djalante, R.; Ebi, K.; Engelbrecht, F.; Guiot, J.; et al. Impacts of $1.5^{\circ} \mathrm{C}$ Global Warming on Natural and Human Systems. In Global Warming of 1.5 C. An IPCC Special Report on the Impacts of Global Warming of $1.5^{\circ} \mathrm{C}$ above Pre-Industrial Levels and Related Global Greenhouse Gas Emission Pathways, in the Context of Strengthening the Global Response to the Threat of Climate Change, Sustainable Development, and Efforts to Eradicate Poverty; Masson-Delmotte, V., Zhai, P., Portner, H.-O., Roberts, D., Skea, J., Shukla, P.R., Piranji, A., Moufouma-Okia, W., Pean, C., Pidock, R., et al., Eds.; World Meteorological Organization Technical Document: Geneva, Switzerland, 2018; In Press.

5. Spinoni, J.; Vogt, J.V.; Naumann, G.; Barbosa, P.; Dosio, A. Will drought events become more frequent and severe in Europe? Int. J. Climatol. 2017, 38, 1718-1736. [CrossRef]

6. Wilhite, D.A. The enigma of drought. In Drought Assessment, Management, and Planning: Theory and Case Studies; Springer: Boston, MA, USA, 1993; pp. 3-15.

7. Steckel, M.; del Río, M.; Heym, M.; Aldea, J.; Bielak, K.; Brazaitis, G.; Černý, J.; Coll, L.; Collet, C.; Ehbrecht, M.; et al. Species mixing reduces drought susceptibility of Scots pine (Pinus sylvestris L.) and oak (Quercus robur L., Quercus petraea (Matt.) Liebl.)-Site water supply and fertility modify the mixing effect. For. Ecol. Manag. 2020, 461, 117908. [CrossRef]

8. Gillerot, L.; Forrester, D.I.; Bottero, A.; Rigling, A.; Lévesque, M. Tree Neighbourhood Diversity Has Negligible Effects on Drought Resilience of European Beech, Silver Fir and Norway Spruce. Ecosystems 2020, 24, 20-36. [CrossRef]

9. Croisé, L.; Lieutier, F.; Cochard, H.; Dreyer, E. Effects of drought stress and high density stem inoculations with Leptographium wingfieldii on hydraulic properties of young Scots pine trees. Tree Physiol. 2001, 21, 427-436. [CrossRef]

10. Nardini, A.; Gullo, M.A.L.; Trifilò, P.; Salleo, S. The challenge of the Mediterranean climate to plant hydraulics: Responses and adaptations. Environ. Exp. Bot. 2014, 103, 68-79. [CrossRef]

11. Nardini, A.; Luglio, J. Leaf hydraulic capacity and drought vulnerability: Possible trade-offs and correlations with climate across three major biomes. Funct. Ecol. 2014, 28, 810-818. [CrossRef]

12. Doffo, G.N.; Monteoliva, S.E.; Rodríguez, M.E.; Luquez, V.M. Physiological responses to alternative flooding and drought stress episodes in two willow (Salix spp.) clones. Can. J. For. Res. 2017, 47, 174-182. [CrossRef]

13. Meier, I.C.; Leuschner, C. Belowground drought response of European beech: Fine root biomass and carbon partitioning in 14 mature stands across a precipitation gradient. Glob. Chang. Biol. 2008, 14, 2081-2095. [CrossRef]

14. Phillips, R.P.; Ibáñez, I.; D’Orangeville, L.; Hanson, P.J.; Ryan, M.G.; McDowell, N.G. A belowground perspective on the drought sensitivity of forests: Towards improved understanding and simulation. For. Ecol. Manag. 2016, 380, 309-320. [CrossRef]

15. Chitra-Tarak, R.; Ruiz, L.; Dattaraja, H.S.; Kumar, M.S.M.; Riotte, J.; Suresh, H.S.; McMahon, S.M.; Sukumar, R. The roots of the drought: Hydrology and water uptake strategies mediate forest-wide demographic response to precipitation. J. Ecol. 2017, 106, 1495-1507. [CrossRef]

16. Pretzsch, H.; Steckel, M.; Heym, M.; Biber, P.; Ammer, C.; Ehbrecht, M.; Bielak, K.; Bravo, F.; Ordóñez, C.; Collet, C.; et al. Stand growth and structure of mixed-species and monospecific stands of Scots pine (Pinus sylvestris L.) and oak (Q. robur L., Quercus petraea (Matt.) Liebl.) analysed along a productivity gradient through Europe. Eur. J. For. Res. 2020, 139, 349-367. [CrossRef] 
17. Fekete, I.; Berki, I.; Lajtha, K.; Trumbore, S.; Francioso, O.; Gioacchini, P.; Montecchio, D.; Várbíró, G.; Béni, A.; Makádi, M.; et al. How will a drier climate change carbon sequestration in soils of the deciduous forests of Central Europe? Biodegradation 2020, 152, 13-32. [CrossRef]

18. Osman, K.T. Organic Matter of Forest Soils. In Forest Soils; Springer: Berlin/Heidelberg, Germany, 2013 ; pp. 63-76.

19. Olson, J.S. Energy Storage and the Balance of Producers and Decomposers in Ecological Systems. Ecology 1963, 44, 322-331. [CrossRef]

20. Marin, C.; Bouten, I.; Dekker, S. Forest floor water dynamics and root water uptake in four forest ecosystems in northwest Amazonia. J. Hydrol. 2000, 237, 169-183. [CrossRef]

21. Gosz, J.R.; Likens, G.E.; Bormann, F.H. Organic matter and nutrient dynamics of the forest and forest floor in the Hubbard Brook forest. Oecologia 1976, 22, 305-320. [CrossRef]

22. Sayer, E. Using experimental manipulation to assess the roles of leaf litter in the functioning of forest ecosystems. Biol. Rev. 2005, 81, 1-31. [CrossRef]

23. Sun, J.; Yu, X.; Li, H.; Chang, Y.; Wang, H.; Tu, Z.; Liang, H. Simulated erosion using soils from vegetated slopes in the Jiufeng Mountains, China. CATENA 2016, 136, 128-134. [CrossRef]

24. Xia, L.; Song, X.; Fu, N.; Cui, S.; Li, L.; Li, H.; Li, Y. Effects of forest litter cover on hydrological response of hillslopes in the Loess Plateau of China. CATENA 2019, 181, 104076. [CrossRef]

25. Helvey, J.D. A summary of rainfall interception by certain conifers of North America. In Proceedings of the International Symposium for Hydrology Professors; Purdue University: Lafayette, IN, USA, 1971; pp. 103-113.

26. Sun, X.; Wang, G.; Lin, Y.; Liu, L.; Gao, Y. Intercepted rainfall in Abies fabri forest with different-aged stands in southwestern China. Turk. J. Agric. For. 2013, 37, 495-504.

27. Huber, A.M.; Oyarzun, C.E. Redistribución de las precipitaciones en un bosque siempreverde del sur de Chile. Turrialba 1992, 42, 192-199.

28. Ilek, A.; Kucza, J.; Szostek, M. The effect of stand species composition on water storage capacity of the organic layers of forest soils. Eur. J. For. Res. 2014, 134, 187-197. [CrossRef]

29. Acharya, B.S.; Stebler, E.; Zou, C.B. Monitoring litter interception of rainfall using leaf wetness sensor under controlled and field conditions. Hydrol. Process. 2016, 31, 240-249. [CrossRef]

30. Prescott, C.E.; Vesterdal, L. Effects of British Columbia Tree Species on Forest Floor Chemistry. In Tree Species Effects in Soils: Implications for Global Change; Springer: Berlin/Heidelberg, Germany, 2006; Volume 55, pp. 17-29.

31. Zagyvai-Kiss, K.A.; Kalicz, P.; Szilágyi, J.; Gribovszki, Z. On the specific water holding capacity of litter for three forest eco-systems in the eastern foothills of the Alps. Agric. For. Meteorol. 2019, 278, 107656. [CrossRef]

32. Peters, M.; Iverson, L.R.; Matthews, S. Long-term droughtiness and drought tolerance of eastern US forests over five decades. For. Ecol. Manag. 2015, 345, 56-64. [CrossRef]

33. Fernald, A.; Gallegos, J.; VanLeeuwen, D.; Baker, T.T. Evaluation of litter hydrology in ponderosa pine and mixed conifer stands in northen New Mexico, USA. New Mex. Acad. Sci. 2012, 4, 121-136.

34. State Forests. National Forest Inventory in Poland. Results for the Period of 2015-2019; Biuro Urządzania Lasu i Geodezji Leśnej: Warsaw, Poland, 2020.

35. Kucza, J.; Urbaś, J. Water absorption of organic matter taken from horizons of ectohumus of forest soils under Norway spruce stands. EJPAU Forestry 2005, 8, 50-58.

36. Ilek, A.; Szostek, M.; Kucza, J.; Stanek-Tarkowska, J.; Witek, W. The water absorbability of beech (Fagus sylvatica l.) and fir (Abies alba mill.) organic matter in the forest floor. Ann. For. Res. 2014, 62. [CrossRef]

37. Ilek, A.; Kucza, J.; Morkisz, K. Hygroscopicity of the bark of selected forest tree species. iForest-Biogeosciences For. 2017, 10, 220-226. [CrossRef]

38. Eckenwalder, J.E. Conifers of the World: The Complete Reference. Timber Press: Portland, OR, USA, 2009.

39. Krakau, U.-K.; Liesebach, M.; Aronen, T.; Lelu-Walter, M.-A.; Schneck, V. Scots Pine (Pinus sylvestris L.). In Forest Tree Breeding in Europe; Springer: Berlin/Heidelberg, Germany, 2013; Volume 25, pp. 267-323.

40. Durrant, T.H.; De Rigo, D.; Caudullo, G. Pinus Sylvestris in Europe: Distribution, Habitat, Usage and Threats. In European Atlas of Forest Tree Species. Publication Office of the European Union: Luxembourg, 2016; pp. 132-133.

41. Björse, G.; Bradshaw, R. 2000 years of forest dynamics in southern Sweden: Suggestions for forest management. For. Ecol. Manag. 1998, 104, 15-26. [CrossRef]

42. Šamonil, P.; Vrška, T. Trends and cyclical changes in natural fir-beech Forests at the north-western edge of the Carpathians. Folia Geobot. Phytotaxon. 2007, 42, 337-361. [CrossRef]

43. Vrška, T.; Adam, D.; Hort, L.; Kolář, T.; Janík, D. European beech (Fagus sylvatica L.) and silver fir (Abies alba Mill.) rotation in the Carpathians-A developmental cycle or a linear trend induced by man? For. Ecol. Manag. 2009, 258, 347-356. [CrossRef]

44. Walsh, R.P.D.; Voigt, P.J. Vegetation Litter: An Underestimated Variable in Hydrology and Geomorphology. J. Biogeogr. 1977, 4, 253. [CrossRef]

45. Kramer, P.J.; Boyer, J.S. Water Relations of Plants and Soils; Academic Press: San Diego, CA, USA, 1995.

46. The Gymnosperm Database. Available online: https://www.conifers.org/ (accessed on 20 October 2021). 
47. Scartazza, A.; Dibaccio, D.; Bertolotto, P.; Gavrichkova, O.; Matteucci, G. Investigating the European beech (Fagus sylvatica L.) leaf characteristics along the vertical canopy profile: Leaf structure, photosynthetic capacity, light energy dissipation and photoprotection mechanisms. Tree Physiol. 2016, 36, 1060-1076. [CrossRef]

48. North Carolina Extension Gardener Plant Toolbox. Available online: https:/ / plants.ces.ncsu.edu/ (accessed on 20 October 2021).

49. Caudullo, G.; Tinner, W.; de Rigo, D. Picea Abies in Europe: Distribution, Habitat, Usage and Threats. In European Atlas of Forest Tree Species; San-Miguel-Ayanz, J., de Rigo, D., Caudullo, G., Houston Durrant, T., Mauri, A., Eds.; Publications Office of the European Union: Luxembourg, 2016; pp. 114-116.

50. Putuhena, W.M.; Cordery, I. Estimation of interception capacity of the forest floor. J. Hydrol. 1996, 180, 283-299. [CrossRef]

51. Gerrits, A.M.J. The Role of Interception in the Hydrological Cycle. Ph.D. Thesis, Delft University of Technology, Delft, The Netherlands, 2010.

52. Sato, Y.; Kumagai, T.; Kume, A.; Otsuki, K.; Ogawa, S. Experimental analysis of moisture dynamics of litter layers? The effects of rainfall conditions and leaf shapes. Hydrol. Process. 2004, 18, 3007-3018. [CrossRef]

53. Guevara-Escobar, A.; Gonzalez-Sosa, E.; Ramos-Salinas, M.; Hernandez-Delgado, G.D. Experimental analysis of drainage and water storage of litter layers. Hydrol. Earth Syst. Sci. 2007, 11, 1703-1716. [CrossRef]

54. Zema, D.A.; Ii, J.T.V.S.; Plaza-Alvarez, P.A.; Xu, X.; Carra, B.G.; Lucas-Borja, M.E. Effects of stand composition and soil properties on water repellency and hydraulic conductivity in Mediterranean forests. Ecohydrology 2021, 14. [CrossRef]

55. Zhang, Z.; Chen, Y.; Zhang, Z.; Cui, H.; Lei, Y.; Wang, D.; Sui, J. Water-holding characteristics of litter in different forests at the Lianxiahe watershed. Front. For. China 2006, 1, 413-418. [CrossRef]

56. Zhang, Z.; Lei, Y.; Su, K.; Wang, G.; Wang, D.; Ma, H. Hydrological characteristics of litter in different forest succession stages at Liuxihe Watershed, southern China. Front. For. China 2009, 4, 317-322. [CrossRef]

57. Kara, O.; Bolat, I.; Cakıroglu, K.; Senturk, M.E. Litter decomposition and microbial biomass in temperate forests in North-western Turkey. J. Soil Sci. Plant Nutr. 2014, 14, 31-41.

58. Błońska, E.; Lasota, J.; Januszek, K. Relation between properties of humus horizon and oak participation in a Scots pine stands. Soil Sci. Annu. 2013, 64, 82-87. [CrossRef]

59. Hart, S.C.; Firestone, M.K.; Paul, E.A. Decomposition and nutrient dynamics of ponderosa pine needles in a Mediterranean-type climate. Can. J. For. Res. 1992, 22, 306-314. [CrossRef]

60. Chen, S.; Cao, T.; Tanaka, N.; Gao, T.; Zhu, L.; Zou, C. Hydrological properties of litter layers in mixed forests in Mt. Qinling, China. iForest-Biogeosci. For. 2018, 11, 243-250. [CrossRef] 